\title{
Transcription Factor p65
}

National Cancer Institute

\section{Source}

National Cancer Institute. Transcription Factor p65. NCI Thesaurus. Code C17686.

Transcription factor p65 (551 aa, $\sim 60 \mathrm{kDa}$ ) is encoded by the human RELA gene. This protein is involved in the modulation of both signaling and gene expression. 